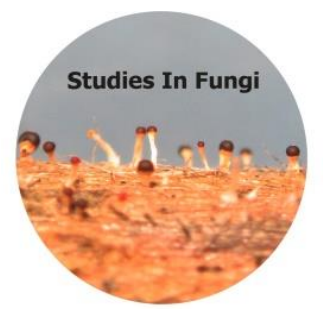

Studies in Fungi 3(1): 333-342 (2018) www.studiesinfungi.org ISSN 2465-4973

Article

Doi 10.5943/sif/3/1/33

\title{
Fungal contaminations of indoor and outdoor air of buildings of the University of Cape Coast, Ghana
}

\author{
Yafetto $\mathbf{L}^{1^{*}}$ and Adator $\mathbf{E H}^{2}$
}

${ }^{1}$ Department of Molecular Biology and Biotechnology, School of Biological Sciences, College of Agriculture and Natural Sciences, University of Cape Coast, Cape Coast, Ghana

${ }^{2}$ Department of Food Science, Faculty of Agriculture and Food Sciences, University of Manitoba, Winnipeg, Canada

Yafetto L, Adator EH 2018 - Fungal contaminations of indoor and outdoor air of buildings of the University of Cape Coast, Ghana. Studies in Fungi 3(1), 333-342, Doi 10.5943/sif/3/1/33

\begin{abstract}
The presence of microscopic spores in the air affects the quality of air inhaled by animals including humans. Microbial contamination of air impacts the well-being of occupants of an indoor environment, sometimes with dire consequences. The study investigated fungal contaminations of indoor and outdoor air of the Hospital, Library and Senior Common Room (SCR) of the University of Cape Coast, Ghana. Indoor and outdoor air was sampled using the Koch's sedimentation method. Colony forming units per cubic meter of air $\left(\mathrm{cfu} / \mathrm{m}^{3}\right)$ were determined with the Omeliansky formula. The isolated fungi were identified based on morphological and growth characteristics. For indoor air, the least colony counts were recorded in the SCR for both morning and afternoon samples, whilst the Hospital air had the highest colony counts. For outdoor air, the colony counts were lower in SCR and the Library for both morning and afternoon samples compared to the Hospital. The results further indicated that indoor concentrations of fungi, for morning and afternoon, ranged between $4.0 \times 10^{4}$ and $2.1 \times 10^{5} \mathrm{cfu} / \mathrm{m}^{3}$, whereas outdoor concentrations of fungi ranged between $1.1 \times 10^{5}$ and $3.0 \times 10^{5} \mathrm{cfu} / \mathrm{m}^{3}$, revealing an overall higher levels of contamination of outdoor air than indoor air at all the three buildings. Consequently, estimated indoor/outdoor (I/O) concentration ratios of fungi revealed an exogenous source of indoor contaminations at all the three buildings sampled. Fungi isolated from indoor and outdoor air were of the genera Aspergillus, Curvularia, Cylindrocarpon, Fusarium, Mucor, Neurospora, Penicillium and Rhodotorula. We conclude that indoor and outdoor air of the buildings sampled were contaminated with airborne fungi; however, based on estimated I/O ratios, the indoor ambient conditions of the buildings were good. The implication of findings of this study is that the presence of airborne fungal contaminants of indoor and outdoor workplace environment may pose serious occupational health consequences, hence low productivity.
\end{abstract}

Key words - airborne fungi - Ghana - indoor air quality - microbial contaminants - occupational health workplace environment

\section{Introduction}

Animals including humans inhale millions of microbial spores from the time of birth to the time of death (Money 2004). Most of these microbial spores are airborne; they form bioaerosols, which are mostly bacterial endospores, fungal spores, and other organic materials, and serve as potential agents of contaminations, infections and allergens (Karwowska 2003). The possible 
sources of airborne indoor microbial spores include: (i) inhabitants of buildings and their indoor activities, (ii) organic dust from stored materials in buildings, (iii) outdoor climate, and (iv) air inflowing from ventilation and air conditioning systems (Karwowska 2003, Kalwasińska et al. 2012). Microbial spores, apart from being airborne, are microscopic. The presence of these microscopic spores in the air affects the quality of air inhaled and negatively impacts the health of both animals and humans. For example, immunocompromised individuals may be allergic or highly prone to falling ill when they inhale some of the microbial spores. Because humans spend between $85-90 \%$ of their time indoors, indoor air quality (IAQ) remains one of the most peculiar parameters that is critically examined when the health and well-being of occupants in a building are considered (Dacarro et al. 2003, Chen \& Zhao 2011). Therefore, it is not surprising that the study of microbes and their airborne, microscopic spores dates back to more than a century (Wells 1955, Greene et al. 1962). The interest in IAQ heightened in the 1970s, at a time when an increasing number of office workers complained of headaches, dizziness, nausea, fatigue, cough, and other related ailments. These ailments were vaguely defined and blamed on inadequate ventilation and the presence of chemical pollutants in the indoor environment (Money 2004). Since the cause was unknown then, the term sick building syndrome was used as a catch-all diagnosis for most patients who reported these ailments (Money 2004). The significance of IAQ remains a considerable occupational and public health interest to environmental microbiologists, researchers, homeowners, industrial hygienists, building engineers, attorneys and health workers.

Studies of IAQ have reported the presence of airborne microbial spores in classrooms and libraries of educational institutions (Karwowska 2003, Karbowska-Berent et al. 2011, Canha et al. 2012, Kalwasińska et al. 2012). Other studies have focused on hospitals, where cases of allergies and other ailments associated with the sick building syndrome had occurred (Björnsson et al. 1995, Newson et al. 2000, Meklin et al. 2002, Karwowska 2003, Stryjakowska-Sekulska et al. 2007, Harkawy et al. 2011, Kalwasińska et al. 2012). The impact of such studies of microbial IAQ on improvement of workplace environments and occupational health in Western Europe and North America, particularly the United States of America, justifies more investigations into microbial IAQ and their ramifications on the well-being of occupants of indoor environments. This justification incentivizes similar studies in the developing world, especially Ghana, where the level of knowledge and the extent of scientific inquiries into microbial IAQ are extremely low because of the following reasons: (i) lack of appreciation of health implications of contaminated indoor and outdoor environments, (ii) existence of few environmental health experts, and (iii) lack of institutions interested in or mandated by law to perform widespread microbial IAQ assessment of homes, offices, schools, hospitals, restaurants, hotels, among others.

All year round, thousands of students and staff of educational institutions in Ghana spend several hours in enclosed spaces, such as cafeteria, classrooms, halls of residence, infirmaries/hospitals, lecture halls, libraries, and recreational centers, to teach, study, work, exercise, relax and seek healthcare. These students and staff are unsuspectingly confronted with the stark reality of exposure to airborne microbes and microbial spores that contaminate the air and affect the IAQ, which ultimately impact their health and well-being. Hence, there is the need to assess the air quality of buildings frequently used in order to ensure they do not pose serious health hazards. Therefore, the aim of this study was to assess the fungal air contamination of three of the most frequently occupied buildings of the University of Cape Coast, Ghana.

\section{Material and Methods}

\section{Study Sites}

The study was conducted at the University of Cape Coast, Ghana. Cape Coast $\left(5^{\circ} 7^{\prime} 53.44^{\prime \prime}\right.$ North, $1^{\circ} 16^{\prime} 53.11^{\prime \prime}$ West) is a historic coastal town in Southern Ghana. It boasts some of the best educational institutions in Ghana, including two universities - University of Cape Coast and Cape Coast Technical University (Yafetto \& Osei-Bonsu 2017). The University of Cape Coast was selected for this present study. Indoor and outdoor air were sampled at the Hospital, Library and 
Senior Common Room (SCR) of the university. Specifications, characteristics and specific areas, where the indoor air of the buildings were sampled are presented in Table 1.

Table 1 Detailed specifications and characteristics of buildings sampled.

\begin{tabular}{lllll}
\hline $\begin{array}{l}\text { Building } \\
\text { sampled }\end{array}$ & $\begin{array}{l}\text { Year } \\
\text { built }\end{array}$ & $\begin{array}{l}\text { Indoor area } \\
\text { sampled }\end{array}$ & Installations & Construction and layout \\
\hline Hospital & 1964 & $\begin{array}{l}\text { Out Patients } \\
\text { Department }\end{array}$ & $\begin{array}{l}\text { Natural } \\
\text { ventilation }\end{array}$ & $\begin{array}{l}\text { Mostly wooden; windows } \\
\text { sealed with nylon sieves } \\
\text { and Louvre blades; } \\
\text { interior furnished with } \\
\text { chairs }\end{array}$ \\
\hline Library & 1999 & Lobby & Air condition & $\begin{array}{l}\text { Mostly concrete; sealed } \\
\text { glass windows and doors; } \\
\text { interior furnished with } \\
\text { wooden chairs, tables, and } \\
\text { bookshelves }\end{array}$ \\
& & & & \\
& & & & \\
& & & & \\
\end{tabular}

\begin{tabular}{lll}
\hline SCR $2010 \quad$ Coffee Lounge & Air condition & $\begin{array}{l}\text { Mostly concrete; sealed } \\
\text { glass windows and doors; } \\
\text { interior furnished with } \\
\text { couches, dining tables and } \\
\text { chairs }\end{array}$ \\
\end{tabular}

\section{Sampling of Air at Buildings}

Air of both indoor and outdoor was sampled twice a day (8:00 a.m. and 12:00 p.m.) over a period of 5 weeks. Indoor air was sampled at the Out Patients Department (OPD) of the Hospital, the lobby of the Library and the coffee lounge of the SCR (Table 1). Outdoor air was sampled approximately $10 \mathrm{~m}$ from the main entrances to the buildings.

Air was sampled with the Koch's sedimentation method (Awad \& Mawla 2012, Hameed \& Habeeballah 2013, Koszałkowska et al. 2014). Approximately $39 \mathrm{~g}$ of Potato Dextrose Agar (PDA) powder was dissolved in $1 \mathrm{~L}$ distilled water and autoclaved at $1.1 \mathrm{~kg} / \mathrm{cm}^{2}$ for 15 minutes at $121^{\circ} \mathrm{C}$. The PDA culture medium was supplemented with chloramphenicol to inhibit bacterial growth. Petri plates containing about 20-ml aliquots of the chloramphenicol-supplemented PDA were exposed to indoor and outdoor air at a height of $1.5 \mathrm{~m}$ from the floor for 5 minutes. The Petri plates were incubated at $25^{\circ} \mathrm{C}$ for 7 days. Fungal colonies were enumerated with a digital colony counter and expressed as colony forming units per cubic meter of air $\left(\mathrm{cfu} / \mathrm{m}^{3}\right)$ using the Omeliansky formula, $\mathrm{N}$ $=5 \mathrm{a} \times 10^{4}\left(\mathrm{bt}^{-1}\right)$, where, $\mathrm{N}$ is colony forming units per cubic meter of air, a is number of colonies per Petri dish, $\mathrm{b}$ is dish square centimeter, and t represents time of exposure (minutes).

\section{Indoor/Outdoor Concentration Ratios of Fungi}

The Indoor/Outdoor ( $\mathrm{I} / \mathrm{O})$ concentration ratios of fungi isolated from indoor and outdoor air for each building were derived from Table 2 using the following formula:

$$
\mathrm{I} / \mathrm{O} \text { concentration ratio }=\frac{\text { Indoor Concentration of Fungi }}{\text { Outdoor Concentration of Fungi }}=1
$$

where $\mathrm{I} / \mathrm{O}$ concentration ratio greater than $(>) 1$ denotes endogenous source of indoor air contamination whilst $\mathrm{I} / \mathrm{O}$ ratio less than $(<) 1$ denotes exogenous source of indoor air contamination. 


\section{Fungal Identification}

A piece of fungal culture was collected with an inoculation needle unto an alcohol-sterilized glass slide, after which the fungal culture was covered in a drop of lactophenol cotton blue dye for 3 minutes. The sample was then covered with a cover slip. Excess dye was removed with a Whatman No. 1 filter paper and the sample allowed to dry. The prepared slides were observed under a Celestron LCD Deluxe Digital Microscope (Model \#44345, Celestron ${ }^{\circledR}$, China). Micrographs of fungal spores were captured with the microscope's in-built camera. Images of fungal cultures were captured with Nikon D5100 digital camera (Nikon Corporation, Thailand). Microscopic identification of the fungi was based on morphological and growth features in consultations with the relevant identification manuals (Barnett \& Hunter 1995, Ellis et al. 2007, Pitt \& Hocking 2009, Watanabe 2010, Campbell et al. 2013).

\section{Results and Discussion}

\section{Fungal Contaminations of Indoor and Outdoor Air}

Results of this study revealed the presence of airborne fungi in the indoor and outdoor air of the Hospital, Library and SCR, and the extent to which these buildings sampled were contaminated by fungal aerosols. The indoor concentrations of fungi in the morning and afternoon ranged from $4.0 \times 10^{4}-2.1 \times 10^{5} \mathrm{cfu} / \mathrm{m}^{3}$, whereas concentrations of fungi obtained outdoor ranged from $1.1 \times 10^{5}-$ $3.0 \times 10^{5} \mathrm{cfu} / \mathrm{m}^{3}$ (Table 2). These results suggest that (i) air of both outdoor and indoor was contaminated with airborne fungi, and (ii) the outdoor environments were more contaminated than the indoor environments leading to an exogenous source of indoor contaminations at all the three buildings sampled. These findings are in agreement with those by Gutarowska \& Jakubowska (2002), Tsai et al. (2002), Stryjakowska-Sekulska et al. (2007), Kalwasińska et al. (2012) and show similar pattern of occurrence of fungal aerosols in indoor and outdoor air of buildings.

The air sampled inside the SCR in the morning had the lowest concentration of fungi $\left(6.6 \times 10^{4} \mathrm{cfu} / \mathrm{m}^{3}\right)$, whereas that for the Hospital had highest concentration of fungi $\left(1.6 \times 10^{5} \mathrm{cfu} / \mathrm{m}^{3}\right)$ as shown in Table 2. Similar trend of concentrations was obtained in the afternoon from indoor air of the three buildings; with the SCR having the lowest concentration of fungi $\left(4.0 \times 10^{4} \mathrm{cfu} / \mathrm{m}^{3}\right)$ while the Hospital had the highest concentration $\left(2.1 \times 10^{5} \mathrm{cfu} / \mathrm{m}^{3}\right)$.

The trend of contamination of outdoor air by fungal spores in the morning was similar to that for indoor air. However, the data for the afternoon samples indicated that the concentration for the Library samples was the lowest, being $1.1 \times 10^{5} \mathrm{cfu} / \mathrm{m}^{3}$ followed by SCR and then the Hospital with the highest contaminated samples (Table 2).

That the Hospital air was the most contaminated of the three buildings sampled, may be attributed to the age, construction and layout of the hospital, which allowed for unrestrained inflow of air from the outdoor into the indoor environment of the OPD (Table 1). Indeed, the wooden components of the Hospital building might have served as a suitable substrate of support to fungal growth and production of microscopic spores that are dislodged into the air. Moreover, activities of the health workers (doctors, nurses, paramedics) and patients could further introduce fungal spores into the indoor and outdoor air of the hospital specifically through movements of hospital equipment, undeliberate agitations of windows and furniture, and cleaning activities of janitors at the facility. It is possible that the relatively high concentrations of fungal spores observed in air at the hospital could pose a high risk of nosocomial infections of its occupants and patients presenting at the hospital.

Hence, we infer that (i) the number of occupants in a room, their activities including dusting of furniture, vacuum cleaning, etc., and the inflow of outdoor air into the inner environment of the hospital can contribute to microbial IAQ, and that (ii) rooms with efficient ventilation and air conditioning system, and guaranteed air tightness are less contaminated compared to rooms without such facilities (Stryjakowska-Sekulska et al. 2007, Chen \& Zhao 2011, Harkawy et al. 2011, Kalwasińska et al. 2012, Adams et al. 2015). 
Table 2 Concentrations of airborne fungi isolated from indoor and outdoor air of the Hospital, Library and SCR.

\begin{tabular}{clll}
\hline \multirow{2}{*}{ Environment } & \multirow{2}{*}{ Building Sampled } & \multicolumn{2}{c}{ Colony forming units/m } \\
\cline { 3 - 4 } & & Morning & Afternoon \\
\hline \multirow{2}{*}{ Outdoor } & Hospital & $3.0 \times 10^{5}$ & $2.3 \times 10^{5}$ \\
& Library & $2.0 \times 10^{5}$ & $1.1 \times 10^{5}$ \\
& SCR & $1.2 \times 10^{5}$ & $2.1 \times 10^{5}$ \\
\hline \multirow{2}{*}{ Indoor } & Hospital & $1.6 \times 10^{5}$ & $2.1 \times 10^{5}$ \\
& Library & $1.4 \times 10^{5}$ & $9.3 \times 10^{4}$ \\
& SCR & $6.6 \times 10^{4}$ & $4.0 \times 10^{4}$ \\
\hline
\end{tabular}

\section{Indoor/Outdoor Concentration Ratio of Isolated Fungi}

Indoor/Outdoor (I/O) concentration ratio, which is equal to 1, suggests that the microbial concentration in an indoor air must be equal to that obtained for an outdoor air (StryjakowskaSekulska et al. 2007). This further suggests that when I/O concentration ratio is less than 1 then the indoor fungal contamination of air has exogenous source of fungal spores. In this study, interestingly, analyses of the $\mathrm{I} / \mathrm{O}$ concentration ratios of fungi for the three buildings, derived from data in Table 2, revealed that, indeed, indoor fungal contaminations of air originated from exogenous sources (Table 3). This finding supports those by Tsai et al. (2002), Tsai \& Macher (2005), Soto et al. (2009), who have reported exogenous sources of indoor contaminations of air in their studies.

Table 3 Indoor/Outdoor concentration ratios of airborne fungi isolated from indoor and outdoor air of the Hospital, Library and SCR.

\begin{tabular}{lll}
\hline \multirow{2}{*}{ Building sampled } & \multicolumn{2}{c}{ I/O concentration ratios } \\
\cline { 2 - 3 } & Morning & Afternoon \\
\hline Hospital & 0.53 & 0.91 \\
Library & 0.70 & 0.85 \\
SCR & 0.55 & 0.20 \\
\hline
\end{tabular}

Rao et al. (1996) extensively reviewed the quantitative standards and guidelines for fungi in indoor air by governmental and private organizations. In this review, Rao et al. (1996) emphasized the dangers of exposure to fungal aerosols as they cause human diseases. However, they also pointed out that (i) the methods for assessing exposure remained poorly understood, and (ii) approaches employed to interpreting data were often contradictory. Chen \& Zhao (2011) shared similar views in their review. This notwithstanding, Brickus et al. (1998), de Aquino Neto \& de Góes Siqueira (2000) have proposed I/O concentration ratios for indoor ambient conditions in buildings, where, I/O concentration ratio $\leq 1.5$ indicates "good indoor ambient conditions"; I/O concentration ratio between 1.5 and 2.0 indicates "regular indoor ambient conditions"; and I/O > 2 indicates "poor indoor ambient conditions". We therefore deduce from the I/O concentration ratios of the current study, based on the proposal by Brickus et al. (1998), de Aquino Neto \& de Góes Siqueira (2000), that the indoor ambient conditions in the buildings sampled were good (Table 3).

\section{Identification of Fungi Isolated from Indoor and Outdoor Air}

Microscopic analyses based on morphological and growth features including mycelial growth pattern, spore size, spore shape, conidial arrangement, and hyphal disposition were used to identify fungi that were isolated using relevant literature. Diverse genera of fungi isolated from the Hospital, Library and SCR included Aspergillus, Curvularia, Cylindrocarpon, Fusarium, Mucor, Neurospora, Penicillium and Rhodotorula (Table 4, Figs 1, 2). 
Aspergillus and Penicillium are well-known opportunistic fungal pathogens of humans, and are often associated with allergy, aspergillosis, rhinitis, asthma, and conjunctivitis, presenting them as potential candidates involved in the sick building syndrome (Jones 1999, Schwab \& Straus 2004). Brickus et al. (1998), Karwowska (2003), Stryjakowska-Sekulska et al. (2007) have reported some of these allergenic and toxic fungal species in offices and university rooms. Remarkably, Aspergillus and Penicillium were isolated from all the buildings sampled except that for the outdoor air of the Hospital, Aspergillus was not isolated, and for indoor air of the Library, Penicillium was not isolated (Table 4). Heida et al. (1995) have reported Aspergillus and Penicillium as the two most predominant genera of fungi isolated from a composting facility.

Interestingly, two opportunistic human pathogens, Cladosporium and Alternaria, well-known to have adverse effects on the health of teachers and students in schoolrooms were reported by Stryjakowska-Sekulska et al. (2007) but were not isolated in this study (Table 4). However, Hameed \& Habeeballah (2013), Koszałkowska et al. (2014) have reported the presence of Cladosporium and Alternaria in a mosque and food processing plants. This further confirms the good air quality of the buildings assessed in the current study.

Table 4 Fungi isolated from indoor and outdoor environments of the three buildings sampled.

\begin{tabular}{|c|c|c|c|c|c|}
\hline \multicolumn{6}{|c|}{ Building Sampled } \\
\hline Hospital & & Library & & SCR & \\
\hline Indoor & Outdoor & Indoor & Outdoor & Indoor & Outdoor \\
\hline A. flavus & Cuvularia sp. & A. flavus & A. flavus & A. niger & A. niger \\
\hline A. japonicus & Fusarium sp. & A. niger & A. niger & A. japonicus & A. japonicus \\
\hline A. ochraceus & N. crassa & $\begin{array}{l}\text { Curvularia } \\
\text { sp. }\end{array}$ & Curvularia sp. & Curvularia sp. & Curvularia sp. \\
\hline Curvularia sp. & P. expansum & $\begin{array}{l}\text { Fusarium } \\
\text { sp. }\end{array}$ & N. crassa & $\begin{array}{l}\text { Cylindrocarpon } \\
\text { sp. }\end{array}$ & P. expansum \\
\hline $\begin{array}{l}\text { Mucor sp. } \\
\text { N. crassa }\end{array}$ & P. funiculosum & $\begin{array}{l}\text { Mucor sp. } \\
\text { N. crassa }\end{array}$ & P. funiculosum & $\begin{array}{l}\text { P. expansum } \\
\text { Rhodotorula } \\
\text { sp. }\end{array}$ & Rhodotorula sp. \\
\hline P.expansum & & & & & \\
\hline
\end{tabular}

Curvularia, a known fungal pathogen of plants, was the most consistently isolated fungi from all three buildings in both indoor and outdoor air (Table 4). The consistent isolation of Curvularia may be attributed to their association to the vegetation on the University campus, coupled with some level of farming activities by local famers of surrounding communities of the University such that its spores could be liberated, become airborne, and carried to the indoor and outdoor air of buildings (Figs 1,2).

The occurrence of Rhodotorula and Cylindrocarpon was consistently localized to the indoor of the SCR. Rhodotorula is of public health interest for two reasons: (i) it has recently gained prominence and, at the same time, notoriety as an emerging human pathogen that causes a type of fungal infection called fungemia, and (ii) it is a typical foodborne fungus with the capacity to produce mycotoxins (Zaas et al. 2003, Tuon \& Costa 2008, Wirth \& Goldani 2012). It is therefore possible that the occurrence of Rhodotorula at the SCR might pose a significant health threat to immunocompromised individuals who patronized the facility particularly if they consume contaminated food and drinks served there.

Cylindrocarpon is another fungal pathogen that causes root rot and black foot diseases in plants and has the capacity to cause spoilage of food in storage at the SCR. It is therefore not a coincidence that Rhodotorula and Cylindrocarpon were consistently isolated from the SCR because of their association with farm produce and other plant materials in storage (Fig. 1). The isolation of Rhodotorula in this study is consistent with observations made by Wanner et al. (1993) who detected other yeasts in most indoor air. Surprisingly, the genus Neurospora, was consistently 
isolated mainly from both the indoor and outdoor air of the Hospital and Library, but not the SCR (Table 4).

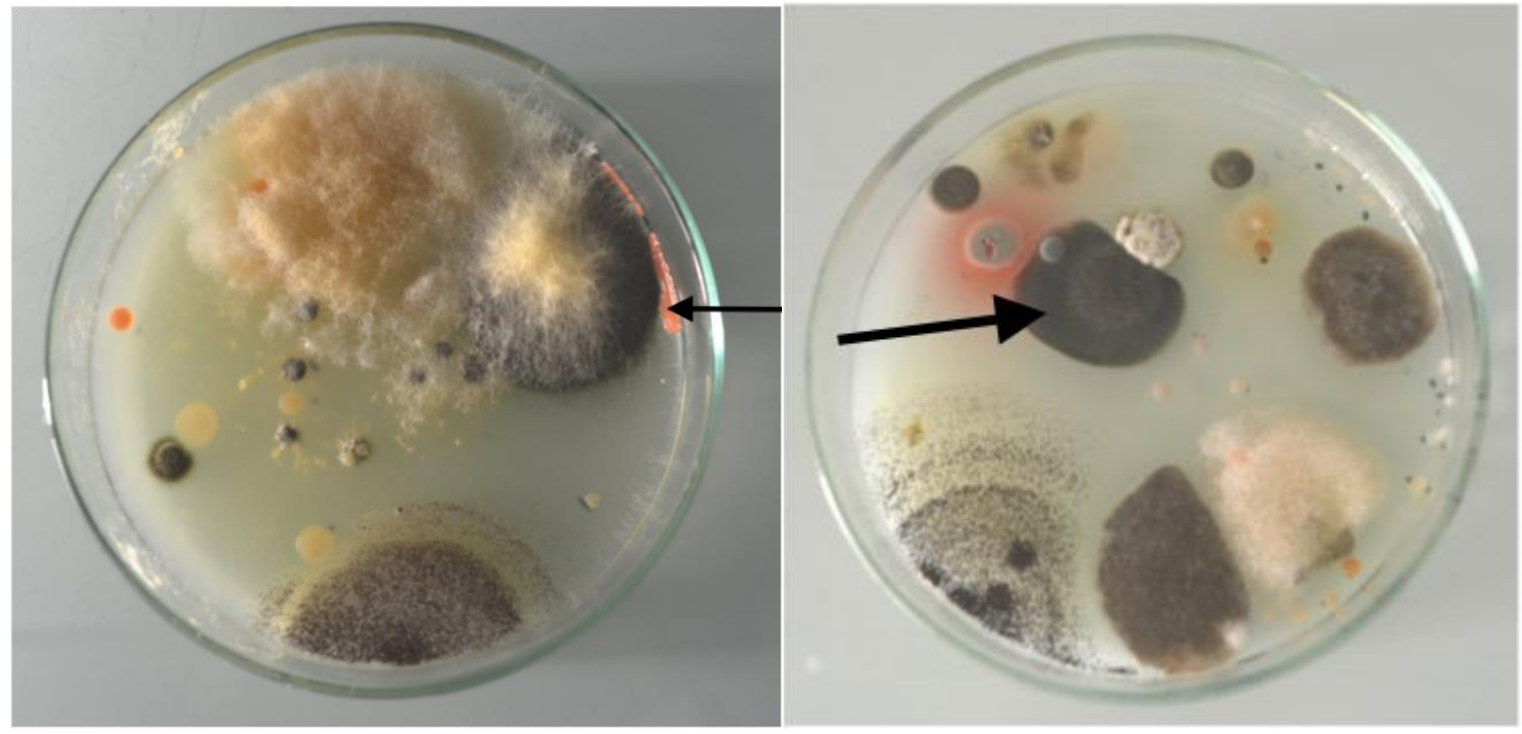

Fig. 1 - Fungal colonies isolated from indoor (left) and outdoor (right) air at the SCR and the Library, respectively. Rhodotorula sp. (arrowed, left) was isolated only from the SCR. Curvularia sp. (arrowed, right) was the most commonly isolated fungus from the three buildings.

The isolation of the diverse genera of fungi in this study supports findings by Hameed \& Habeeballah (2013), Koszałkowska et al. (2014), who reported fungi from the genera Acremonium, Alternaria, Aspergillus, Chaetomium, Cladosporium, Epicoccum, Mucor, Penicillium, Trichoderma, and Trichophyton in their studies.

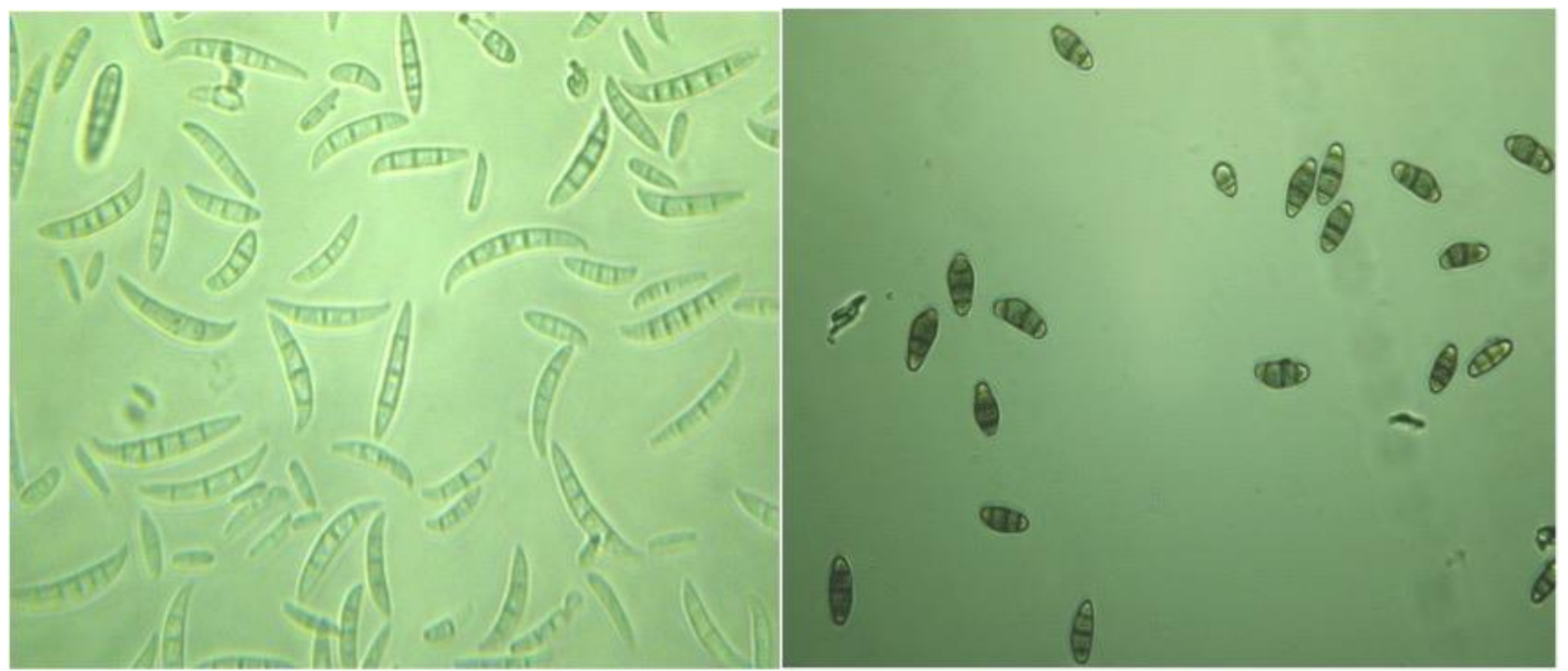

Fig. 2 - Micrographs of segmented spores of Fusarium (left) and Curvularia (right).

We conclude from this study that both indoor and outdoor air of the Hospital, Library and the SCR are contaminated by fungi, but outdoor concentrations of fungal aerosols were higher compared to indoor concentrations, therefore resulting in exogenous source of indoor contaminations air of the buildings. Furthermore, some fungi isolated, such as Aspergillus, Cylindrocarpon, Fusarium, and Rhodotorula are toxigenic human and plant pathogens, thus, may pose serious public health threats to visitors to buildings we sampled in this study. 
Implications of findings from this study is that the University may incur losses when these patrons to these buildings fall ill as a result of infections from their exposure to these fungi, which will ultimately affect the overall productivity of the staff and students.

We recommend (i) a comprehensive public education on potential health hazards of microbial air contaminations, (ii) provision and proper maintenance of ventilation and air condition systems in buildings of educational institutions, and (iii) regular fumigation of workplaces including educational institutions. Future studies should investigate the extent of contamination by bacteria in the Hospital, Library and SCR. Findings from such studies will provide further insight into the extent of microbial contamination of buildings of this university, fill the gap in knowledge of microbial IAQ in Ghana, and help inform policies on safety and regulation in order to deal with occupational health and protect occupants of workplace environments.

\section{Acknowledgements}

The authors are grateful to the service staff of the University of Cape Coast for granting us permission to sample the buildings used in this study. We thank also the technical staff of the Department of Molecular Biology and Biotechnology, University of Cape Coast, for the technical assistance during the study.

\section{References}

Adams RI, Bhangar S, Pasut W, Arens EA et al. 2015 - Chamber bioaerosol study: Outdoor air and human occupants as sources of indoor airborne microbes. PLoS ONE 10(5): e0128022. doi:10.1371/journal.pone.0128022.

Awad AH, Mawla HA. 2012 - Sedimentation with the Omeliansky formula as an accepted technique for quantifying airborne fungi. Polish Journal of Environmental Studies 21(6), 1539-1541.

Barnett HL, Hunter BB. 1995 - Illustrated genera of fungi imperfecti. Scotland, UK: Burgess.

Björnsson E, Norbäck D, Janson C, Widström J et al. 1995 - Asthmatic symptoms and indoor levels of micro-organisms and house dust mites. Clinical and Experimental Allergy 25, 423431.

Brickus LSR, Siqueira LFG, de Aquino Neto FR, Cardoso JN. 1998 - Occurrence of airborne bacteria and fungi in Bayside offices in Rio de Janeiro, Brazil. Indoor and Built Environment 7, 270-275.

Campbell CK, Johnson EM, Warnock DW. 2013 - Identification of pathogenic fungi. (2nd Ed.). London, UK: Wiley-Blackwell.

Canha N, Martinho M, Almeida-Silva M, Freitas MC et al. 2012 - Indoor air quality in primary schools. International Journal of Environment and Pollution 50, 396-410.

Chen C, Zhao B. 2011 - Review of relationship between indoor and outdoor particles: I/O ratio, infiltration factor and penetration factor. Atmospheric Environment 45(2), 275-288.

Dacarro C, Picco AM, Grisoli R, Redolfi M. 2003 - Determination of aerial microbiological contaminations in scholastic sports environment. Journal of Applied Microbiology 95, 904912.

de Aquino Neto FR, de Góes Siqueira LF. 2000 - Guidelines for indoor air quality in offices in Brazil. Proceedings of Healthy Buildings 4, 549-554.

Ellis D, Davis S, Alexiou H, Handke R, Bartley R. 2007 - Descriptions of medical fungi (2nd Ed.). Adelaide, Australia.

Greene VW, Vesley D, Bond RG, Michealsen GS. 1962 - Microbiological contamination of hospital air II. Qualitative studies. Applied Microbiology 10, 567-571.

Gutarowska B, Jakubowska A. 2002 - The estimation of moulds air pollution in university settings. In T. Jedrzejewska-Scibak \& J. Sowa (Eds.), Problems of indoor air quality in Poland (pp. 103-112). Warsaw: Publishing House of Warsaw University of Technology. 
Hameed AAA, Habeeballah T. 2013 - Air microbial contamination at the Holy Mosque, Makkah, Saudi Arabia. Current World Environment 8(2), 179-187.

Harkawy A, Górny RL, Ogierman L, Wlazło A et al. 2011 - Bioaerosol assessment in naturally ventilated historical library building with restricted personnel access. Annals of Agricultural and Environmental Medicine 18, 23-329.

Heida H, Bartman F, van der Zee SC. 1995 - Occupational exposure and indoor air quality monitoring in a composting facility. American lndustrial Hygiene Association Journal 56, $39-43$.

Jones AP. 1999 - Indoor air quality and health. Atmospheric Environment 33, 4535-4564.

Kalwasińska A, Burkowska A, Wilk I. 2012 - Microbial air contamination in indoor environment of a university library. Annals of Agricultural and Environmental Medicine 19, 25-29.

Karbowska-Berent J, Górny RL, Strzelczyk AB, Wlazło A. 2011 - Airborne and dust borne microorganisms in selected Polish libraries and archives. Building and Environment 46, $1872-1879$.

Karwowska E. 2003 - Microbiological air contamination in some educational settings. Polish Journal of Environmental Studies 12, 181-185.

Koszałkowska M, Kręcidło L, Krzyśko-Łupicka T. 2014 - Microbiological analysis of bioaerosol in food industry. Proceedings of ECOpole, 8(1), 43-47.

Meklin T, Husman T, Vepsäläinen A, Vahteristo M et al. 2002 - Indoor air microbes and respiratory symptoms of children in moisture damaged and reference schools. Indoor Air 12, $175-183$.

Money NP. 2004 - Carpet monsters and killer spores. New York: Oxford University Press. p. 12.

Newson R, Strachan D, Corden J, Millington W. 2000 - Fungal and other spore counts as predictors of admission for asthma in the Tent region. Occupational and Environmental Medicine 57, 786-792.

Pitt JI, Hocking AD. 2009 - Fungi and food spoilage (3rd Ed.). New York, Springer.

Rao CY, Burge HA, Chang JCS. 1996 - Review of quantitative standards and guidelines for fungi in indoor air. Journal of the Air and Waste Management Association 26(9), 899-908. Doi: $10.1080 / 10473289.1996 .10467526$.

Schwab CJ, Straus DC. 2004 - The roles of Penicillium and Aspergillus in sick building syndrome. Advanced Applied Microbiology 55, 215-238.

Soto T, Murcia RMG, Franco A, Vicente-Soler J et al. 2009 - Indoor airborne microbial load in a Spanish university (University of Murcia, Spain). Anales de Biologia. 31, 109-115.

Stryjakowska-Sekulska M, Piotraszewska-Pajak A, Szyszka A, Nowicki M, Filipiak M. 2007 Microbiological quality of indoor air in university rooms. Polish Journal of Environmental Studies 16, 623-632.

Tsai FC, Macher JM. 2005 - Concentrations of airborne culturable bacteria in 100 large US office buildings from the BASE study. Indoor Air 15, 71-81.

Tsai FC, Macher JM, Hung YY. 2002 - Concentrations of airborne bacteria in 100 U.S. office buildings. Proceedings: Indoor Air. 353-358.

Tuon FF, Costa FS. 2008 - Rhodotorula infection. A systematic review of 128 cases from literature. Revista Iberoamericana Micologia 25, 135-140.

Wanner HU, Verhoeff A, Colombi A, Flannigan B et al. 1993 - Biological particles in indoor environments. In Indoor air quality and its impact on man. Commission of European Communities, Report No. 12. Brussels.

Watanabe T. 2010 - Pictorial atlas of soil and seed fungi; morphologies of cultured fungi and key to species. (3rd Ed). New York: CRC Press.

Wells WF. 1955 - Airborne contagion and air hygiene. Cambridge, Massachusetts: Harvard University Press.

Wirth F, Goldani LZ. 2012 - Epidemiology of Rhodotorula: An emerging pathogen. Interdisciplinary Perspectives on Infectious Diseases. Article ID.465717. doi:10.1155/2012/465717. 
Yafetto L, Osei-Bonsu V. 2017 - Ethnomycological survey of Cape Coast Metropolis, Ghana. Current Research in Environmental and Applied Mycology 7(4), 258-266. Doi $10.5943 /$ cream/7/4/2.

Zaas AK, Boyce M, Schell W, Lodge AB et al. 2003 - Risk of fungemia due to Rhodotorula and antifungal susceptibility testing of Rhodotorula isolates. Journal of Clinical Microbiology 41, 5233-5235. 